\title{
MANAJEMEN KEWIRAUSAHAAN PESANTREN DALAM MENUMBUHKAN JIWA ENTREPENEUR
}

\section{ENTREPRENEURIAL MANAGEMENT OF ISLAMIC BOARDING SCHOOL IN FOSTERING THE ENTREPRENEURSHIP SPIRIT}

\author{
ZK Latifah ${ }^{1}$ dan VA Rahmayanti1a \\ 1 Program Studi Manajemen Pendidikan Islam, Fakultas Keguruan dan Ilmu Pendidikan, \\ Universitas Djuanda Bogor, Jl. Tol Ciawi No. 1 Kotak Pos 35 Ciawi Bogor 16720 \\ a Korespondensi: Veni Ayu Rahmayanti, Email: ayuraveni@gmail.com \\ (Diterima: 17-02-2017; Ditelaah: 19-01-2017; Disetujui: 14-04-2017)
}

\begin{abstract}
Entrepreneurial management Islamic boarding school the utilization of economic potential in a creative, innovative, and courage to face risks to earn profits by systematically planned and can be evaluated properly, accurate, and complete so as to achieve objectives in a productive, high quality, effective and efficient. Entrepreneurial management so that schools can also be regarded as an element in education for the success of the program in educational organizations and expediting the process of education is not as excessive media benefit. Agriculture Darul Fallah Bogor Islamic boarding school is the institution that is a focus on selfdevelopment in entrepreneurship so that learners can product independently minded generation. From this background, the authors are interested in examining these educational institutions with the aim to determine the application of entrepreneurial management schools, the impact of the application of entrepreneurial management schools in growing spirit of entrepreneurship and entrepreneurial management Islamic boarding school real contribution in fostering entrepreneurship spirit. The result of research shows that Agriculture Darul Fallah Bogor Islamic boarding school is an educational institution that has a pretty good entrepreneurial management pattern. It is proved by the existence of entrepreneurship management that can develop entrepreneurship spirit of students and real contribution from entrepreneurship management that is material contribution so that can help in boarding school economy, moral contribution in the form of support from various cooperation partners that can give benefit to boarding school. And contribution from graduated Agriculture Darul Fallah Bogor Islamic boarding school who has become a successful entrepreneurship in helping pesantren in the form of material and training for the students.
\end{abstract}

Keywords: entrepreneurship, management, school, spirit.

\begin{abstract}
ABSTRAK
Manajemen kewirausahaan pesantren adalah unsur dalam pendidikan yang dapat mensukseskan dan memperlancar proses pendidikan dalam pendayagunaan potensi ekonomis secara kreatif dan inovatif dengan terencana secara sistematis dan dapat dievaluasi secara benar sehingga mencapai tujuan yang diharapkan. Pesantren Pertanian Darul Fallah Bogor adalah lembaga pendidikan yang berfokus pada pengembangan diri peserta didiknya dibidang kewirausahaan sehingga dapat menghasilkan generasi yang berjiwa mandiri.Jenis penelitian ini merupakan penelitian kualitatif, dengan pendekatan studi kasus.Dalam pengumpulan data penulis menggunakan metode observasi, wawancara dan dokumentasi.Hasil dari penelitian menunjukan bahwa Pesantren Pertanian Darul Fallah
\end{abstract}


Bogor adalah lembaga pendidikan yang memiliki pola manajemen kewirausahaan pesantren yang sesuai dengan konsep manajemen kewirausahaan pesantren.Dibuktikan dengan kontribusi riil lulusan alumni Pesantren Pertanian Darul Fallah Bogor.

Kata kunci: entrepreneurship, jiwa, kewirausahaan, manajemen, pesantren.

Latifah ZK dan VA Rahmayanti. 2017. Manajemen kewirausahaan pesantren dalam menumbuhkan jiwa entrepeneur. Tadbir Muwahhid 1(1): 42-56.

\section{PENDAHULUAN}

Salah satu permasalahan dalam dunia pendidikan di Indonesia adalah semakin meningkatnya pengangguran tenaga kerja terdidik akibat dari pola pikir bahwa setelah lulus hanya untuk mencari pekerjaan, bukan menciptakan lapangan pekerjaan. Akan tetapi semakin sempitnya pertumbuhan lapangan kerja sehingga jumlah pengangguran semakin meningkat dalam tiap tahunnya, maka hal tersebut akan berdampak pada pembangunan negara. Pembangunan negara dapat dikatakan berhasil apabila jumlah pengangguran dapat berkurang dikarnakan wirausahawan yang bisa membuka lapangan pekerjaan.

Berdasarkan data Badan Pusat Statistik (BPS) pada bulan Agustus tahun 2015, dari angkatan kerja sebanyak 122,4 juta jiwa pengangguran di Indonesia mencapai jumlah 7,56 juta jiwa atau 6,18\%. Mayoritas pengangguran merupakan angkatan kerja terdidik (Ramadhan, Republika Online).

Dalam mengatasi persoalan tenaga kerja maka bangsa Indonesia sudah saatnya mencari terobosan dan memikirkan dengan menanamkan nilai-nilai kewirausahaan sedini mungkin di kalangan terdidik. Penanaman nilai-nilai kewirausahaan diharapkan dapat membangun jiwa berwirausaha sehingga tidak bergantung pada pencarian kerja yang semakin sempit dan ketat persaingannya.

Pesantren adalah salah satu lembaga pendidikan yang concern terhadap kewirausahaan, dikarenakan pada batasan tertentu pesantren berhasil merintis dan menunjukan kemandiriannya dalam hal penyelenggaraan ataupun dalam pendanaan. Penanaman semangat kemandirian dan kewirausahaan yang tidak menggantungkan diri kepada orang lain telah menjadi kegiatan pendidikan yang konsisiten dan relatif berhasil di pesantren (Ismail et al2002).

Rasulullah SAW telah mengajarkan kepada umatnya agar senantiasa berwirausaha karenakan seorang pedagang mempunyai kedudukan yang tinggi. Dijelaskan dalam hadist berikut: "Pedagang yang jujur lagi terpercaya adalah bersamasama para Nabi, orang shadiqiin dan para syuhada" (HR. Tirmidzi dan Hakim).

Pesantren yang menerapkan kewirausahaan bagi para santrinya yaitu Pesantren Pertanian Darul Fallah Bogor. Dari awal berdiri pondok pesantren tersebut sudah menerapkan ilmu pengetahuan dan keterampilan dalam bidang agrobisnis dan kewirausahaan, dimana seluruh kegiatan usaha dari proses awal produksi hingga hasil produksi dikerjakan oleh para santri dengan terbimbing. Pesantren Pertanian Darul Fallah Bogor beralamatkan di Jalan Raya Ciampea Km 12 Bogor mempunyai visi untuk mewujudkan lembaga pendidikan yang menghasilkan SDM yang memiliki ruhul jihad, kreatif, inovatif dan mandiri. Dengan visi tersebut diharapkan Pesantren Pertanian Darul Fallah Bogor menjadi lembaga pendidikan yang memberikan solusi bagi masalah pengangguran yang 
semakin meningkat dalam tiap tahunnya terutama untuk angkatan kerja terdidik.

Sektor usaha yang dijalankan di Pesantren Pertanian Darul Fallah Bogor bergerak dalam bidang seperti agrobisnis, produksi dan jasa. Bidang usahanya terdiri atas: (1) PT Dafa Tekno Agro Mandiri (perbanyakan bibit tanaman/kultur jaringan), (2) peternakan terpadu (sapi perah, kambing perah, penggemukan sapi potong dan domba, pabrik pakan ternak kapasitas produksi 100 ton/hari), (3) koperasi (simpan pinjam, warung dan pupuk organik), (4) perikanan (air tawar), (5) organic farming, (6) pengolahan hasil peternakan (susu pasteurisasi, youghurt dan keffir), (7) pengolahan hasil pertanian (nata de coco, aloe vera/lidah buaya, dan lain-lain).

Berdasarkan fokus dan subfokus penelitian diatas maka rumusan masalah dalam penelitian ini adalah efektivitas penerapan manajemen kewirausahaan dalam menumbuhkan jiwa entrepreneurship di Pesantren Pertanian Darul Fallah Bogor. Pertanyaan penelitian sebagai berikut.

1. Bagaimana penerapan manajemen kewirausahaan pesantren dalam menumbuhkan jiwa entrepreneurship di Pesantren Pertanian Darul Fallah Bogor?

2. Bagaimana dampak penerapan manajemen kewirausahaan pesantren dalam menumbuhkan jiwa entrepreneurship di Pesantren Pertanian Darul Fallah Bogor?

3. Bagaimana pengembangan dan kontribusi riil manajemen kewirausahaan dalam menumbuhkan jiwa entrepreneurship di Pesantren Pertanian Darul Fallah Bogor?

Untuk memberikan arahan yang jelas tentang maksud dari penelitian ini serta berdasar pada fokus dan subfokus jang diajukan, maka penelitian ini bertujuan untuk mendeskripsikan dan menganalisis:

1. Penerapan manajemen kewirausahaan pesantren dalam menumbuhkan jiwa entrepreneurship di Pesantren Pertanian Darul Fallah Bogor.

2. Dampak penerapan manajemen kewirausahaan pesantren dalam menumbuhkan jiwa entrepreneurship di Pesantren Pertanian Darul Fallah Bogor.

3. Kontribusi riil dari pengembangan manajemen kewirausahaan pesantren dalam menumbuhkan jiwa entrepreneurship di Pesantren Pertanian Darul Fallah Bogor.

\section{MATERI DAN METODE}

\section{Materi}

\section{Manajemen Kewirausahaan}

Manajemen adalah sebuah proses dimana menentukan langkah yang sistematis dan terpadu dengan memberdayakan semua potensi yang ada baik personal maupun material secara efektif dan efisien (Prihatin 2011). Dengan demikian maka manajemen merupakan suatu proses yang berkelanjutan dimana seseorang berkemampuan dan mempunyai keterampilan khusus dibidang pengelolaan dalam mengkoordinasi dan menggunakan segala sumber daya untuk mencapai tujuan organisasi secara produktif, efektif dan efisien (Komariah 2012).

Istilah lain kewirausahaan yang sering dipakai yaitu wirausaha. Istilah wirausaha berasal dari bahasa Perancis "enterprende" yang dalam terjemahan bahasa Inggrisnya yaitu "between taker" yang artinya mengambil pekerjaan (Alma 2016). Kewirausahaan (entrepreneurship) adalah ilmu yang mempelajari tentang perilaku seseorang yang mempunyai kemampuan 
dalam menghadapi tantangan hidup dengan berbagai resiko yang mungkin dihadapinya (Suryana 2003).

Jadi dapat disimpulkan bahwa manajemen kewirausahaan adalah pemberdayaan potensi ekonomis secara inovatif dan menerima resiko untuk mendapatkan laba dengan sistematis dan terencana sehingga dapat di evaluasi secara akurat untuk mencapai tujuan yang diharapkan.

\section{Fungsi Manajemen Kewirausahaan}

\section{Perencanaan}

Menurut George R. Terry dan Leslie W. R sebagaimana dikutip oleh Nana Herdiana Abdurrahman memberikan definisi bahwa perencanaan adalah proses memutuskan tujuan-tujuan yang hendak dilakukan dan hal-hal yang akan dilaksanakan selama jangka waktu yang akan datang agar tujuantujuan itu dapat tercapai (Abdurrahman 2013). Menurut Beierlein, Schneeberger, dan Osburn dalam E. Gumbira Sa'id dan A. Haritz Intan, mengemukakan bahwa perencanaan dapat dilakukan pada bidang produksi, pemasaran, persediaan, keuangan, dan lainlain (Intan 2004). Tujuannya untuk perusahaan agar dapat ditempatkan pada posisi terbaik di masa yang akan datang.

\section{Pengorganisasian}

Pengertian dari pengorganisasian yaitu menempatkan dan menggerakan semua sumber daya perusahaan untuk mencapai tujuan yang hendak dicapai (Intan 2004). Menurut Downey dan Erickson sebagaimana yang dikutip oleh E. Gumbira Sa'id dan A. Haritz Intan (Intan 2004), fungsi pengorganisasian tersebut meliputi kegiatan-kegiatan antara lain:
a. menyusun struktur organisasi;
b. menentukan pekerjaan yang harus dikerjakan;

c. memilih, menempatkan, dan mengembangkan karyawan;

d. merumuskan garis kegiatan perusahaan;

e. membentuk sejumlah hubungan dalam organisasi dan kemudian menunjuk staf.

\section{Pengarahan}

G. R. Terry dan L. W. Rui dalam Nana Hendriana Abdurrahman mendefinisikan pengarahan sebagai mengintegrasikan usaha-usaha anggota dan kelompok sedemikian rupa dengan tugas-tugas yang diserahkan kepada anggota telah selesai, sehingga memenuhi tujuan-tujuan kelompok (Abdurrahman 2013). Jadi pengarahan meliputi usaha untuk memimpin, mengawasi, memotivasi, mendelegasi dan menilai. Fungsi pengarahan dapat juga diartikan secara lebih luas, yaitu sebagai tugas untuk menciptakan kondisi agar dapat menumbuhkan minat kerja para karyawannya, menumbuhkan pemikiran yang imajinatif dan membuat organisasi tetap hidup. Tujuan ini dapat dicapai dengan mutu kepemimpinan yang ditunjukan oleh manajer.

\section{Pengawasan}

Pengawasan adalah proses untuk mengukur dan menilai pelaksanaan dalam suatu kegiatan organisasi apakan berhasil ataukah terjadi penyimpangan dan hambatan sehingga dapat dikoreksi untuk memperlancar tercapainya tujuan (Firdaus 2009).

\section{Evaluasi}

Evaluasi sebagai fungsi manajemen kewirausahaan yang artinya menilaisebuah kegiatan yang dilakukan apakah telah sukses atau gagal dalam mencapai tujuan sehingga dapat dijadikan bahan kajian untuk berikutnya. Dalam mengkaji indikator masalah yang di hadapi ketika mengevaluasi maka rumusan solusi alternatif dapat 
memperbaiki kelemanahan-kelemahan yang ada dan meningkatkan kualitas keberhasilan dimasa yang akan datang (Intan 2004).

\section{Pengertian Pesantren}

Menurut Anwar et al. (2013), pesantren didefinisikam sebagai salah satu model pendidikan Islam di Indonesia yang mempunyai ciri khas tersendiri dimana terdapat asrama sebagai tempat tinggal santri yang bersifat permanen (Anwar et al. 2013).

Adapun fungsi pesantren salah satunya ialah sebagai lembaga pendidikan, lembaga sosial dan pusat penyiaran agama Islam di Indonesia. Pesantren juga terkenal mampu memainkan peranan dalam pembangunan salah satunya adalah pembangunan ekonomi masyarakat dengan memberdayakan kemandirian kepada santrinya (Hafidhuddin 2001).

\section{Jiwa Entepreneurship}

Keberhasilan suatu usaha tidak terlepas dari jiwa entrepreneurship seorang wirausahawan, jika jiwa entrepreneurship sudah tertanam dalam diri seseorang wirausahawan maka besar kemungkinan dapat menjadi wirausahawan yang sukses dikemudian hari. Seseorang yang memiliki jiwa entrepreneurship menurut Suryana (2003) memiliki beberapa kriteria sebagai berikut.

a. Kepercayaan terhadap diri sendiri (mempunyai jiwa optimis dan berkomitmen).

b. Berinisiatif (seseorang yang selalu berenergik).

c. Berjiwa pemimpin (berani tampil beda).

d. Kemampuan untuk menerima resiko dan penuh perhitungan (karena suka akan tantangan).

\section{Konsep Dasar kemitraan}

Menurut Muhammad Jafar Hafsah dalam Budi Setyo Hutomo kemitraan adalah suatu strategi bisnis agar dapat meraih keuntungan yang dilakukan oleh dua pihak atau lebih dalam jangka waktu tertentu dengan prinsip saling membesarkan dan saling membutuhkan (Hutomo 2013). Handayani (2015) menyebutkan bahwa dengan menjalin kemitraan maka ada beberapa macam pola kemitraan antara lain sebagai berikut.

a. Pola inti plasma

b. Pola subkontrak

c. Pola dagang umum

d. Pola keagenan

e. Pola waralaba

f. Bentuk-bentuk lainnya.

\section{Metode}

\section{Tempat dan Waktu Penelitian}

Penelitian manajemen kewirausahaan dalam menumbuhkan jiwa entrepreneurship di Pesantren Pertanian Darul Fallah Bogor, yang beralamatkan di Jalan Benteng No. 35 Ciampea Kabupaten Bogor atau $2 \mathrm{Km}$ dari kampus IPB Dramaga.

\section{Metode Penelitian}

Penelitian ini termasuk kedalam pendekatan kualitatif karena bertujuan mengetahui, memahami dan menghayati dengan seksama secara mendalam tentang bagaimana manajemen kewirausahaan yang dilakukan oleh pesantren tersebut, dan metode penelitian yang sesuai dengan penelitian ini adalah studi kasus (Gunawan 2014).

Penelitian studi kasus adalah penelitian fenomena tertentu secara apa adanya dan secara sederhana, dengan menggunakan berbagai sumber data, sebagai upaya untuk mencapai validitas (kredibilitas) dan 
realibilitas (konsisten) penelitian (Gunawan 2014). Dalam Moleong (2011) dijelaskan langkah-langkah dalam melakukan penelitian yang meliputi: (1) tahap pra lapangan; (2) tahap pekerjaan lapangan; (3) tahap analisis data.

\section{Data dan Sumber Data}

Kata-kata dan tindakan sebagai sumber data yang utama dalam penelitian kualitatif. Data juga terbagi kedalam tindakan dan kata-kata, sumber data yang tertulis, toto dan statistik (angka) (Moleong 2011). Arikunto (2010) mengklasifikasikan sumber data menjadi 3 tingkatan huruf "p" dalam bahasa Inggris yaitu: (1) person, (2) palace, dan (3) paper.

Sumber data untuk penelitian ini adalah unsur manusisa dan non manusia. Unsur manusia meliputi ketua yayasan pesantren, pengelola unit usaha pesantren, guru, tata usaha dan para santri. Sedangkan unsur non manusia adalah dokumentasi pesantren (Moleong 2011).

\section{Teknik Pengumpulan Data}

\section{Wawancara}

Pedoman wawancara yang disebutkan Arikunto (2010), secara garis besar ada dua macam, yaitu: (1) pedoman wawancara tidak terstruktur hanya memuat poin-poin pertanyaan; (2) pedoman wawancara terstruktur yaitu pertanyaan dirangkai secara jelas dan terperinci yang menyerupai check list.

Pada penelitian ini menggunakan bentuk wawancara keduanya dimana sebelum melakukan wawancara, pewawancara mempersiapkan pedoman tertulis tentang apa yang akan ditanyakan kepada responden (ketua yayasan pesantren, pengelola unit usaha pesantren, guru, tata usaha dan para santri) dan terkadang hanya menanyakan secara garis besarnya saja. Dalam hal ini peneliti berinteraksi langsung dengan responden sehingga data yang diperoleh akurat dan sesuai peosedur, yang berguna untuk mendapatkan gambaran-gambaran kegiatan dala manajemen kewirausahaan pesantren.

\section{Observasi}

Hardi dalam Sugiyono mengemukakan bahwa, observasi adalah suatu proses yang komplek, yang tersusun dari berbagai proses biologis serta psikologis (Sugiyono 2014). Teknik ini digunakan karena memungkinkan untuk mengamati sendiri secara mendalam fenomena-fenomena yang terjadi secara langsung dan sekaligus mengkroscek bentuk-bentuk data yang berupa tulisan lewat observasi serta komunikasi dan interaksi, peneliti mendapatkan kesempatan untuk mengetahui kebiasaan dan aktivitas disana.

\section{Dokumen}

Pengumpulan data dari sumber non manusia disebut dokumentasi yang terdiri dari dokumen dan rekaman (AR dan Damaianti 2011). Sesuai dengan pandangan tersebut, peneliti menggunakan metode dokumentasi untuk dijadikan alat pengumpul data dari sumber bahan tertulis yang terdiri dari dokumen resmi. Selain itu data dokumentasi dibutuhkan sebagai alat kroscek data yang diperoleh dari hasil wawancara dan observasi. Dokumen bisa berupa foto, dokumen sekolah, dan sebagainya.

\section{Teknik Analisis Data}

Proses analisis data menurut Sugiyono (2014), yaitu: (1) analisis sebelum lapangan yang dilakukan sebelum terjun langsung atau menggunakan data sekunder yang sifatnya sementara untuk menentukan fokus penelitian; (2) analisis data di lapangan yang dilakukan pada saaat terjun langsung dilapangan. Analisis data yang digunakan dalam penelitian ini sebagaimana menurut 
Miles dan Huberman dalam Imam Gunawan yang mengemukakan tiga tahap dalam menganalisis data kualitatif yaitu: (1) reduksi data (data reduction), (2) paparan data (data display), dan (3) penarikan kesimpulan dan verifikasi (conclusion drawing/verfying) (Sugiyono 2014).

\section{Pemeriksaan Keabsahan Data}

Pemeriksaan keabsahan data dibagi menjadi empat kriteria. Kriteria tersebut di antaranya ialah (a) kredibilitas atau derajat kepercayaan (credibility), (b) keteralihan (transferability), (c) kebergantungan (dependability), dan (d) kepastian (confirmability). Masing-masing kriteria akan dilakukan pemeriksaan dengan teknik tertentu yang dapat dilihat pada Tabel 1.

Tabel 1 Ikhtisar teknik pemeriksaan keabsahan data

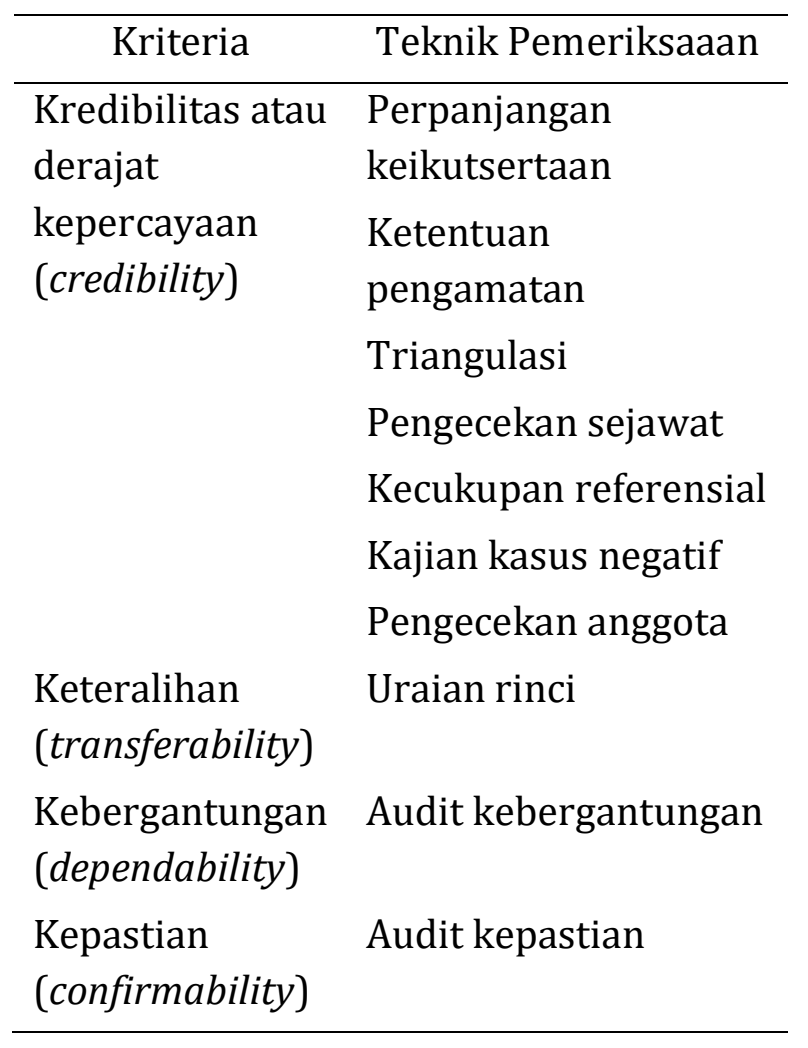

\section{HASIL DAN PEMBAHASAN}

\section{Hasil}

\section{Penerapan \\ Kewirausahaan \\ Perencanaan}

\section{Manajemen \\ Pesantren}

Dalam perencanaannya unit pengolahan susu dafa menyusun rencana usaha untuk memberikan arahan yang jelas dalam upaya mencapai sasaran yang ditetapkan. Dapat diketahui bahwa perencanaan manajemen kewirausahaan unit pengolahan susu dafa di PPDF sebagai berikut.

1. Penyusunan rencana usaha yang dilakukan secara bersama-sama dengan pihak direktur PT Dafa Teknoagro Mandiri, ketua unit peternakan dafa dan ketua unit pengolahan susu dafa.

2. Dalam rencana bisnis unit pengolahan susu dafa dimulai dari:

a. Ringkasan eksekutif

Unit pengolahan susu dafa direncanakan bertempat di PPDF dengan struktur organisasi yang terdiri dari pimpinan kemudian di bawahnya diikuti bagian-bagian yang dibantu pekerja, bagian-bagian itu antara lain: bagian produksi, bagian pengadaan bahan baku, bagian keuangan, dan bagian pemasaran.

b. Deskripsi usaha

1) Data perusahaan

Nama industri: unit pengolahan susu dafa

Tempat: PPDF

Bentuk usaha: UMKM

2) Data pimpinan

Nama: Asmalam S Turnip, A. Md

Pendidikan: S1 
3) Struktur organisasi dan job description

a. Pimpinan: Asmalam S Turnip, A. Md

b. Bagian Produksi: Aisyah dan para santri

c. Bagian bahan baku: Santi

d. Bagian keuangan: Ety Sulastianti, S. Si

e. Bagian pemasaran: Adim

4) Alasan pemilihan bisnis

Usaha ini dipilih karena prospek hasil peternakan dafa dari susu dapi, menjadi susu dapi murni dan youghur sapi untuk sekarang ini cukup menjanjikan, disamping memberikan penghasilan kepada pesantren, memberikan pembelajaran praktikum kepada para santri sehingga memiliki bekal untuk menjadi wirausahawan khususnya dibidang produksi susu sapi, juga untuk menumbuhkan "milk minded" pada masyarakat sekitar pesantren sehingga meningkatkan kesehatan masyarakat, kandungan gizi yang terkandung didalamnya memiliki kandungan gizi yang dibutuhkan manusia serta mudah dalam pembuatannya hanya dengan teknologi dan peralatan yang sederhana, serta tidak perlu keterampilan khusus sehingga siapapun dapat mekakukannya.

c. Analisis pemasaran

\section{1) Product (produk)}

Yoghurt sapi yang telah di produksi akan dipasarkan dengan berbagai jenis kemasan (botol, cup, plastik). Pada kemasan akan diberikan label "Dafa Yoghurt"
2) Place (tempat/distribusi)

Unit pengolahan susu dafa bertempat di PPDF dengan sasaran pasar adalah koperasi PPDF, masyarakat sekitar, warung-warung, supermarket, hingga daerah JABODETABEK (Jakarta, Bogor, Depok, Tanggerang, Bekasi)

3) Price (harga)

Adapun rencana harga jual dari produk youghurt dafa yaitu Rp. 9.000 untuk ukuran stik, Rp. 3.500 untuk kemasan cup, Rp. 4.500 untuk kemasan botol.

4) Promotion (promosi)

Promosi akan dilakukan dengan menempel pamflet-pamflet di pinggir jalan dan tempat-tempat strategis, selain itu juga dengan cara dari mulut ke mulut dan media internet sebagai sarana ebuisness sehingga produk dafa cepat diketahui orang-orang.

d. Analisis operasional

1) Desain produk

Youghurt dafa yang telah diproduksi akan dipasarkan dengan dikemas terlebih dahulu. Maka pada kemasan akan diberikan label "Dafa Youghurt" dan logo perusahaan, nama dan alamat perusahaan, berat atau volume produk. Dengan harapan produknya dapat dikenal oleh konsumen luas, sehingga mudah dicari ketika dibutuhkan.

2) Proses produksi

a) Bahan-bahan yoghurt dafa: susu sapi murni, gula pasir, air, pewarna buatan, bakteri yoghurt(starter). 
b) Cara membuat youghurt dafa: susu sapi murni yang sudah membeku di rendam dalam bak air sampai mencair, rebus susu sapi sampai $80^{\circ}$ celsius, saring masukan kedalam wadah besar dan dinginkan susu sapi sampai $40^{0}$ celcius, ambil sisasisa lemak susu sapi, kemudian masukan bakteri youghurt (starter) kedalam susu sapi untuk takarannya $200 \mathrm{ml}$ bakteri kedalam 10 liter susu sapi, diamkan selama satu malam, setelah itu masak dengan gula pasir, air, pewarna makanan, setelah dimasak kemudian masukan kedalam kemasan dan diberikan label, dan masukan kedalam kulkas.

e. Analisis peluang pasar dan pesaing

1) Analisis peluang pasar

Peluang pasar untuk youghur dafa sangatlah besar dengan melihat budaya masyarakat yang konsumtif dan peluang pasar yang menjanjikan. Selain itu daya beli konsumen terhadap youghurt dafa cukup bervariasi dari konsumen elite hingga menengah ke bawah.

2) Analisis pesaing

Melihat situasi di tempat yang akan dimasuki produk, sepertinya produk youghurt dafa akan laku di pasaran dikarenakan harganya yang terjangkau selain itu untuk pesaing produk youghurt dafa ini tampaknya belum ada untuk di daerah sekitar PPDF.

\section{f. Analisis keuangan}

Total biaya usaha ini adalah $\mathrm{Rp}$. 15.298.625/bulan dan penerimaan per bulan Rp. 18.300.000, sehingga pendapatan perbulannya adalah $\mathrm{Rp}$. 3.001.375 dengan $\mathrm{R} / \mathrm{C}$ ratio sebesar 1,197 dapat dilihat bahwa bisnis yang dipilih layak untuk dilakukan karena pelaku usaha dapat meraup keuntungan dari usaha yang dilakukan $(\mathrm{R} / \mathrm{C}$ ratio $>1)$.

g. Analisis SWOT

1) Strengts (kekuatan): proses pembuatan mudah, harga jual murah, kualitas rasa, tempat penjualan dan konsumen telah tersedia, kemasan menarik, kualitas produk terjamin dan memanfaatkan internet untuk mempromosikan produk.

2) Weaknesses (kelemahan): manajemen perushaan masih sederhana, biaya pemeliharaan peralatan besar, tenaga listrik tidak stabil, keterbatasan waktu praktik para santri karena kurikulum pemerintah, proses produksi bentrok dengan jadwal sekolah santri, ketidak tahuan masyarakat tentang gizi youghurt sapi.

3) Opportunities (peluang): pertumbuhan pasar dimungkinkan meningkat, peluang pasar untuk mendapatkan konsumen yang menjanjikan, belum ada pesaing khususnya untuk pemasaran di daerah PPDF, bahan baku yang mudah diperoleh.

4) Threats (ancaman): selera konsumen yang selalu berubahubah, muncul pesaing baru, iklim yang tidak mendukung seperi musim hujan, banyak variasi minuman ringan, pergantian pemimpin pesantren. 
3. Sosialisasi rencana bisnis yang dilaksanakan oleh ketua unit pengolahan susu dafa kepada para santri melalui mata pelajaran kewirausahaan dan magang yang dapat menumbuhkan kesadaran untuk berjiwa entrepreneurship sehingga nilai-nilai kewirausahaan seperti motivasi berprestasi, kreativitas, memiliki jiwa kepemimpinan dan manajerial dapat terinternalisasikan melalui proses pembelajaran pendidikan kewirausahaan.

\section{Pengorganisasian}

Setelah dilakukan perencanaan maka pengorganisasian unit pengolahan susu dafa di PPDF sebagai berikut.

1. Menyusun struktur organisasi unit pengolahan susu dafa (Tabel 2)

Tabel 2 struktur organisasi unit pengolahan susu dafa PPDF

\begin{tabular}{|c|c|c|}
\hline No & Tugas & Nama \\
\hline 1 & Pimpinan & $\begin{array}{l}\text { Asmalam S Turnip, } \\
\text { A. Md }\end{array}$ \\
\hline 2 & $\begin{array}{l}\text { Bagian } \\
\text { produksi }\end{array}$ & $\begin{array}{l}\text { Aisyah dan para } \\
\text { santri }\end{array}$ \\
\hline 3 & $\begin{array}{l}\text { Bagian bahan } \\
\text { baku }\end{array}$ & Santi \\
\hline 4 & $\begin{array}{l}\text { Bagian } \\
\text { keuangan }\end{array}$ & Ety Sulastianti, S. Si \\
\hline 5 & $\begin{array}{l}\text { Bagian } \\
\text { pemasaran }\end{array}$ & Adim \\
\hline
\end{tabular}

2. Menentukan pekerjaan yang harus dikerjakan berdasarkan job description

a) Jabatan sebagai pemimpin tugas dan tanggung jawabnya adalah mengelola dan sebagai quality control unit pengolahan susu dafa di PPDF.

b) Jabatan kepala bagian produksi tugas dan tanggung jawabnya terhadap persiapan dan proses produksi seta mengkoordinasi bawahannya untuk bekerja sesuai job description

c) Jabatan kepala bagian pengadaan bahan baku tugas dan tanggung jawabnya adalah untuk mencari informasi keberadaan bahan baku, serta menjaga kualitas mutu bahan baku.

d) Jabatan kepala bidang keuangan tugas dan tanggung jawabnya adalah melaksanakan kegiatan keuangan dan administrasi, mencatat keuangan perusahaan dan bertanggung jawab terhadap sistem keuangan.

e) Jabatan kepala bidang pemasaran tugas dan tanggung jawabnya adalah mempromosikan produk ke tempat pemasaran, misalnya kepada mitra kerjasama, toko, warung, atau bahkan supermarket terdekat.

3. Menempatkan karyawan dan melatih karyawan agar dapat bekerja sesuai degan tujuan yang diharapkan unit pengolahan susu dafa.

4. Mengikut sertakan masyarakat sekitar dan para santri dalam proses produksi sampai pengemasan sehingga para santri memahami apa yang dipelajari dari teori dan di praktekan langsung di unit pengolahan susu dafa, dengan begitu maka proses internalisasi nilai budaya organisisasi untuk para santri ini terbentuk melalui peniruan yang diaktualisasikan menjadi kenyataan melalui sikap dan perilaku, sehingga dapat terbentuknya jiwa entrepreneurship para santri seperti mencintai pekerjaan dan produk yang dihasilkannya dan memiliki dedikasi tinggi terhadap bisnisnya.

5. Mempunyai kemitraan usaha dengan pola keagenan dan memasarkan produk 
kepada agen-agen di wilayah JABODETABEK (Jakarta, Bogor, Depok, Tanggerang, Bekasi), warung-warung, dan supermarket salah satunya yaitu serambi botani di mall botani sqwar Bogor.

\section{Pengarahan}

Pengarahan manajemen kewirausahaan unit pengolahan susu dafa di PPDF meliputi:

1. Gaya kepemimpinan kepa unit pengolahan susu dafa adalah gaya kepemimpinan partisipatif yang mana karyawan dan para santri diberikan kesempatan untuk mengambil keputusan, kemudian hasilnya akan diambil voting terbanyak dan disepakati oleh semua anggota.

2. Komunikasi yang terjalin lancar antara pemimpin dan para karyawannya sehingga terjalin pola komunikasi dua arah yang dapat mempererat kerjasama dan tim solid sehingga dapat mencapai tujuan yang diharapkan. Sehingga proses internalisasi nilai-nilai kewirausahaan melalui tindakan keteladanan seorang pemimpin dapat menumbuhkan jiwa entrepreneurship para santri di PPDF.

3. Motivasi yang diberikan kepada karyawan oleh ketua unit pengolahan susu dafa berupa tunjangan hari raya, perhatian dan komunikasi yang baik.

\section{Pengawasan}

Pengawasan manajemen kewirausahaan unit pengolahan susu dafa di PPDF antara lain sebagai berikut.

1. Menentukan standar yang telah ditentukan didalam perencanaan, standar ditentukan dulu sebelum evaluasi dilakukan misalnya unit pengolahan susu dafa dalam satu tahun sudah mencapai standar yang ditentukan
2. Melakukan pengamatan langsung dan mengukur hasil kerja terhadap standar yang sudah ada

3. Memperbaiki penyimpangan bila ada dalam proses produksi, pemasaran atau dalam organisasi unit pengolahan susu dafa.

4. Sosialisasi pengawasan yang dilaksanakan oleh ketua unit pengolahan susu dafa kepada para santri melalui mata pelajaran kewirausahaan dan magang yang dapat menumbuhkan kesadaran untuk berjiwa entrepreneurship sehingga nilai-nilai kewirausahaan seperti reaksi positif terhadap tantangan, responsif terhadap kritikan dan saran yang membangun dapat terinternalisasikan melalui proses pembelajaran

pendidikan kewirausahaan.

\section{Evaluasi}

Evaluasi merupakan fungsi manajemen kewirausahaan dan merupakan fungsi lanjutan dari pengawasan. Maka evaluasi uni pengolahan susu dafa meliputi:

1) rentan waktu manajemen kewirausahaan unit pengolahan susu dafa adalah per satu tahun dengan catatan tiap produksi ada pembukuannya;

2) hasil dari evaluasi manajemen kewirausahaan unit pengolahan susu dafa adalah dalam tiap tahunnya jumlah keuntungan meningkat namun tidak secara signifikan sehingga dapat memberikan pemasukan kepada Yayasan PPDF;

3) untuk pihak yang mengevaluasi dari internal yaitu ketua unit pengolahan susu dafa dan dari pihak eksternal yaitu oleh Kementrian Koperasi dan UMKM Republik Indonesia. 
Sosialisasi evaluasi manajemen kewirausahaan unit pengolahan susu dafa dilakukan melalui pembelajaran mata pelajaran kewirausahaan dan magang sehingga dapat menumbuhkan kesandaran untuk berjiwa entrepreneurship sehingga nilai-nilai kewirausahaan seperti menginspirasi para santri dengan kepercayaan untuk bisa mencapai sasaran usaha, sehingga dapat menjadi entrepreneur yang sukses dan berhasil, dapat terinternalisasikan melalui proses pembelajaran pendidikan kewirausahaan.

\section{Dampak Penerapan Manajemen Kewirausahaan Pesantren}

1. Perencanaan

Dalam perencanaannya manajemen kewirausahaan unit pengolahan susu dafa memberikan dampak yang sangat terasa dikarenakan dapat membina dan mengembangkan kreativitas dan jiwa kepemimpinan para santri, serta menghasilkan pembuatan keputusan rencana usaha yang tepat, cermat dan kontinu sehingga dapat memberikan kemudahan dan manfaat dalam menjalankan unit usaha pengolahan susu dafa.

2. Pengorganisasian

Pengorgansasian dalam unit pengolahan susu dafa dapat membina jiwa kewirausahaan para santri dan masyarakat, memberdayakan sumber daya yang ada di PPDF, membuka peluang usaha bagi masyarakat sekitar, meningkatkan kerja sama dalam bermitra, dan meringankan beban kerja yang ditanggung oleh anggota sehingga berdampak terhadap efisiensi kerja.

3. Pengarahan

Dengan adanya pengarahan dalam unit pengolahan susu dafa maka dapat memberikan dampak berupa terjalinnya komunikasi yang baik dan terhindar dari mis komunikasi yang akan menghambat untuk mencapai tujuan perusahaan, dan meningkatnya kinerja pegawai.

4. Pengawasan

Dengan pengawasan yang dilakukan oleh ketua pengolahan susu dafa maka memberikan dampak terhindar dari penyimpangan-penyimpangan target yang dicapai oleh perusahaan, dapat menumbuhkan jiwa entrepreneurship para santri seperti reaksi positif terhadap tantangan, responsif terhadap kritik dan saran.

5. Evaluasi

Dilakukannya evaluasi berdampak baik bagi unit pengolahan susu dafa dalam mengorekai kesalahan ataupun kekurangan dan dapat memberikan solusi untuk memperbaikinya sehingga dapat menjadi bahan acuan untuk kedepannya, evaluasi juga berdampak pada keyakinan akan keberhasilan para santri untuk menjadi wirausahawan yang sukses dimasa yang akan datang.

\section{Kontribusi Rill dari Pengembangan Manajemen Kewirausahaan Pesantren}

Dengan dimensi keunggulan yang dimiliki Pesantren Pertanian Darul Fallah Bogor menjadikan santri yang bertaqwa, cerdas dan mandiri, serta dapat menumbuhkan jiwa entrepreneurship dengan di dukung mata pelajaran khusus di bidang kewirausahaan agrobisnis seperti budidaya tanaman dan proyek pertanian yang dilakukan setiap pagi dengan pergi ke lahan untuk menanam, merawat, dan memanen hingga memasarkan hasil panennya berupa sayuran kepada masyarakat sekitar maupun diolah oleh para santri. Untuk mata pelajaran PHP (Pengolahan Hasil Pertanian) para santri 
mengolah hasil pertanian menjadi makanan seperti baso jamur tiram, nugget jamur, kue pisang, dll. Mata pelajaran kultur jaringan dan budidaya ikan/ternak yang membuat bibit unggul dan berkualitas dengan fasilitas yang memadai. Serta mata pelajaran koperasi, kewirausahaan dan magang selama 1 bulan menjadikan para santri berjiwa entrepreneurship yang sejati.

Kontribusi rill dari adanya manajemen kewirausahaan Pesantren Pertanian Darul Fallah Bogor dalam menumbuhkan jiwa entrepreneurship par santr dapat dilihat dari keberhsilan mencetak kderder yang a dalam menumbuhkan jiwa entrepreneurship par santr dapat dilihat dari keberhsilan mencetak kderder yang mampu mengembangkan diri dan beriprh di masyarakat. Para alumni yang sudah berhasil menjadi wirausahawan yang sukses meskipun ada beberapa yang masih pada taraf usaha kecil-kecilan.

Karena para alumni ternyata memang telah memiliki benih-benih motivasi yang kuat untuk hidup mandiri sejak di didik di Darul Fallah. Para alumni mempunyai organisasi yang tergabung dalam Ikatan Alumni Darul Fallah (IAD), organisasi inilah yang nantinya akan mengelol para alumni.

\section{Pembahasan}

\section{Gambaran Umum Pesantren Pertanian Darul Fallah Bogor}

Pesantren Pertanian Darul Falah Bogor sejak berdiri telah dipilih kelembagaan yang modern dalam bentuk Yayasan Pesantren Pertanian Darul Falah, organisasi dan personalia pesantren berasal dari badan pengurus yayasan, badan penasehat, pimpinan pesantren. Pimpinan pesantren terdiri atas kepala pesantren, kepala bidang serta kepala urusan yang dilengkapi staf dan karyawan. Pada tingkat santri dan alumni terdapat organisasi Himpunan Siswa Darul Fallah (HISDAF) dan para alumni bergabung dalam Ikatan Alumni Darul Fallah (IAD). Kurikulum pendidikan pesantren memadukan model salaf dengan klasikal, serta memasukan pendidikan pertanian di dalamnya.

Pada tanggal 09 April 1960 Yayasan Pesantren Pertanian Darul Fallah Bogor didirikan dengan menempati lahan wakaf seluas 26, 5 Ha yang beralamatkan di Jalan Raya Bogor Ciampea Km 12 Bogor. Filosofis Darul Fallah adalah berasal dari rumah petani atau kampung pertanian dikarenakan Pesantren Pertanian Darul Fallah Bogor sebagai lembaga pendidikan Islam yang mendalami ilmu pengetahuan dan keterampilan dibidang pertanian dan kewirausahaan untuk semua lapisan masyarakat. Untuk kegiatan belajar mengajar di Madrasah Aliyah Terpadu Darul Fallah Bogor dimuali pada jam 07.45-12.00 kemudian diselang oleh istirahat jam pertama agar peserta didik dapat melaksanakan sholat Dzuhur berjamaah di masing-masing asrama dan setelah itu diberikan waktu istirahat jam makan siang, kemudian masuk lagi pada jam 13.00-15.15 untuk melaksanakan kegiatan belajar mengajar. Proses belajar mengajar ini berlangsung dari hari senin-sabtu dan untuk hari libur ditentukan pada hari minggu. Proses pendidikan dilakukan secara holistik, artinya pendidikan diberikan melalui aktivitas sepanjang waktu dengan memadukan kurikulum Departemen Agama, kepesantrenan, agrobisnis dan kewirausahaan. Kegiatan belajar mengajar menggunakan Kurikulum 2013 yaitu pada kelas X dan kelas XI sedangkan kelas XII menggunakan kurikulum KTSP.

Dengan sistem pendidikan yang ada di Madrasah Aliyah Terpadu Darul Fallah Bogor mempunyai berbagai dimensi keunggulan 
seperti taqwa, menjadikan peserta didik mempunyai aqidah yang lurus (aqidah salimah), Ibadah yang benar (ibadah sahihah), Akhlaq yang mulia (akhlaqul karimah), dimensi keunggulan lainnya yaitu cerdas, menjadikan peserta didik yang berkemampuan intelektual, komunikasi dan teknologi informasi, dimensi keunggulan selanjutnya adalah mandiri, menjadikan peserta didik yang mempunyai jiwa kepemimpinan, berkemampuan manajerial dan jiwa kewirausahaan.

Tabel 3 Program kewirausahaan agrobisnis PPDF

\begin{tabular}{|c|c|c|}
\hline No & $\begin{array}{c}\text { Program } \\
\text { Kewirausahaan }\end{array}$ & Ketua \\
\hline 1 & $\begin{array}{l}\text { Agrowisata } \\
\text { Edukatif }\end{array}$ & Siti Marina, A. Md \\
\hline 2 & $\begin{array}{l}\text { Pembibitan } \\
\text { Kultur Jaringan }\end{array}$ & $\begin{array}{l}\text { Adih Supratman, } \\
\text { S. Pd. I }\end{array}$ \\
\hline 3 & Koperasi & $\begin{array}{l}\text { Emir Farisi, S. } \\
\text { Kom }\end{array}$ \\
\hline 4 & $\begin{array}{l}\text { Perternakan } \\
\text { Terpadu }\end{array}$ & $\begin{array}{l}\text { Hermawan } \\
\text { Maulana, A. Md }\end{array}$ \\
\hline 5 & $\begin{array}{l}\text { Pengolahan } \\
\text { Susu }\end{array}$ & $\begin{array}{l}\text { Asmalam } \quad \mathrm{S} \\
\text { Turnip, A. Md }\end{array}$ \\
\hline 6 & $\begin{array}{l}\text { Pengolahan } \\
\text { Hasil Pertanian }\end{array}$ & $\begin{array}{l}\text { Ety Sulastianti, S. } \\
\text { Si }\end{array}$ \\
\hline 7 & $\begin{array}{l}\text { Budidaya } \\
\text { Ternak Ikan }\end{array}$ & $\begin{array}{l}\text { Adih Supratman, } \\
\text { S. Pd. I }\end{array}$ \\
\hline
\end{tabular}

Dengan visi menjadi lembaga pendidikan, dakwah dan pengembangan masyarakat yang unggul dan menghasilkan sumberdaya manusia yang memiliki ruhul jihad, kreatif, inovatif dan mandiri. Maka Pesantren Pertanian Darul Fallah Bogor mempunyai keunggulan dalam bidang agrobisnis, adapun program kewirausahaan agrobisnis Pesantren Pertanian Darul Fallah diantaranya terdapat pada Tabel 3. Pesantren Pertanian Darul Fallah Bogor menjalin kerjasama di berbagai bidang dalam bentuk kemitraan agar dapat lebih meningkatkan kinerja dan hasil usaha santri, di antaranya sebagai berikut.

1) Masyarakat dan petani sekitar pesantren, berupa pembinaan dan penyaluran hasil produksi masyarakat oleh pesantren.

2) Instansi pemerintah yaitu Kementrian Pertanian Republik Indonesia, Kementrian Koperasi dan UKM Republik Indonesia, berupa pengembangan SDM, bantuan permodalan dan pengembangan sarana prasarana.

3) Lembaga pendidikan yaitu Institut Pertanian Bogor, Universitas Ibn Khaldun Bogor, Universitas Islam Negri, berupa kerjasama pengembangan teknologi pertanian melalui penelitian, magang dan sebagainya .

4) Pihak-pihak lain yang sekiranya dapat memberikan manfaat bagi Pesantren Pertanian Darul Fallah Bogor dalam pengembangan usaha maupun pendidikannya.

Dari sekian banyak program kewirausahaan agrobisnis PPDF, program kewirausahaan pengolahan susu dengan unit usaha pengolahan susu dafa adalah salah satu unit usaha pesantren yang cukup berkembang dalam melaksanakan manajemen kewirausahaan pesantren dikarenakan dengan sistem pengelolaan manajemen kewirausahaan yang melibatkan para santri, sehingga para santri cakap dalam bidang ilmu agama dan ilmu agrobisnis.

\section{KESIMPULAN DAN IMPLIKASI}

\section{Kesimpulan}

Penerapan manajemen kewirausahaan Pesantren Pertanian Darul Fallah Bogor telah dilakukan sesuai dengan fungsi 
manajemen kewirausahaan pesantren yaitu: (1) perencanaan, (2) pengorganisasian, (3) pengarahan, (4) pengawasan, dan (5) evaluasi. Dengan manajemen kewirausahaan pesantren tersebut memberikan dampak dalam membina dan menumbuhkan jiwa entrepreneurship para santri, mengembangkan ekonomi kreatif dibidang agrobisnis, dapat meningkatkan kerjasama dalam bermitra, terbukanya lapangan pekerjaan bagi masyarakat sekitar pesantren, pemberdayaan sumber daya alam secara optimal. Sehingga memberikan kontribusi rill dari adanya manajemen kewirausahaan Pesantren Pertanian Darul Fallah Bogor dengan menumbuhkan jiwa entrepreneurship para santri sehingga banyak lulusan dari PPDF yang menjadi wirausahawan yang sukses dalam berbagai bidang usaha.

\section{Implikasi}

Dari hasil penelitian ini dapat dikembangkan penelitian serupa tentang manajemen kewirausahaan pesantren, serta dapat mengembangkan pendidikan kewirausahaan dalam menumbuhkan jiwa entrepreneurship guna mencapai lulusan terdidik yang mandiri.

\section{DAFTAR PUSTAKA}

Abdurrahman NH. 2010. Manajemen bisnis syariah dan kewirausahaan. Pustaka Setia, Bandung.

Anwar E, D Hafidhuddin, dan E Mujahidin. 2013. Pendidikan kemandirian berbasis pesantren di Pondok Pesantren Modern
Darussalam Gontor Ponorogo. Unida Press, Bogor.

AR Syamsudin dan VS Damayanti. 2011. Metode pendidikan bahasa. Remaja Rosdakarya, Bandung.

Arikunto S. 2010. Prosedur penelitian: suatu pendekatan praktik. Rineka Cipta, Jakarta.

Firdaus M. 2009. Manajemen agrobisnis. Bumi Aksara, Jakarta.

Gunawan I. 2014. Model penelitian kualitatif teori dan praktik. Bumi Aksara, Jakarta.

Hafidhuddin D. 2010. Dakwah aktual. Gema Insani Press, Jakarta.

Hutomo BS. 2013. Enam pilar insektisida kebijakan pengembangan dan penguatan UMKM berbasis kerjasama kemitraan denga pola CSR sebagai strategi peningkatan peran pemerintah dan perusahaan untuk menjaga eksisitensi UMKM dalam MEA 2015. Jurnal Ekonomi Pembangunan. Volume 2 Nomor 2.

Moleong LJ. 2011. metodologi penelitian kualitatif. Remaja Rosdakarya, Bandung.

Prihatin E. 2011. Manajemen peserta didik. Alfabeta, Bandung.

Sa'id EG dan Intan AH. 2004. Manajemen agrobisnis. Ghalia Indonesia, Jakarta.

SM Ismail dkk. 2002. Dinamika pesantren dan madrasah. Pustaka Pelajar, Yogyakarta.

Sugiono. 2014. Metode penelitian kuantitatif kualitatif dan R\&D. Alfabeta, Bandung.

Suryana. 2003. Kewirausahaan: pedoman praktis, kiat dan proses menuju sukses. Saleba Empat, Jakarta.

Trisnawati E dan M Hasanudin. 2016. Manajemen bisnis syariah. Refika Aditama, Bandung. 